\title{
腰部脊柱管狭窄症における春髄造影の意義
}

\author{
青 野 誠* 齊 藤太 * $^{*}$ 入 江 努* \\ 田中哲 也* 末 永 英 慈* 園田和 彦*
}

\section{The Value of Myerography in Lumbar Spinal Canal Stenosis}

\author{
Makoto Aono*, Taichi Saito*, Tsutomu Irie* \\ Tetsuya Tanaka*, Eiji Suenaga*, and Kazuhiko Sonoda*
}

\begin{abstract}
【はじめに】腰部脊柱管狭窄症（以下，LSCS とする）の画像診断において MRI は非侵襲性の有用な検 查である。一方，LSCSは間久跛行を主訴とするため，脊髄造影のように腰椎の動態撮影における神経圧 迫の変化を捉えることも重要である。今回，われわれは両者の相関関係について検討した。【対象と方法】 当院で MRI と脊䯣造影の両検査を実施し， L 4-5 に主病変を有する LSCS 患者 30 例（男性 19 人，女性 11 人，平均年齢 71.4 歳）を対象とした。 L 1 椎体中央レベルを基準とし相対的に L 1-2，2-3，3-4 にお いて MRI と金髄造影動態撮影における硬膜管前後径を比較検討した。【結果】下位レベルほど硬膜管前後 径は狭小化していた。脊䯣造影所見から手術を行った症例が L 2-3，L 3-4で各 3 例あった。動態撮影後 屈位で狭窄が増強する例もあり，MRIのみでLSCS の診断を行うことには注意が必要であると考えられ た.
\end{abstract}

MRI is a noninvasive and useful modality for diagnosing lumbar spinal canal stenosis (LSCS). On the other hand, myelography is also important, because it can evaluate the dynamic factor which is known as characteristic intermittent claudication for LSCS. In this report, we compared the anteroposterior diameter of the dural sac on MRI and myelography, and found that the diameter decreased with lower lumbar levels. There were three patients with LSCS at the L 2-3 and L 3-4 levels respectively who underwent decompression surgery depending on the results of myelography. These results suggest that myelography is necessary to provide preoperative diagnosis for LSCS in addition to MRI.

Key words : lumbar spinal canal stenosis (腰部脊柱管狭乍症), magnetic resonance imaging（磁気共 鳴影像法), myelography (脊髄造影)

\section{は じめに}

現在 MRI は脊䯣造影検査に比べると侵襲性が無い という利点があり, 腰部春柱管狭窄症 (以下 LSCS) を評価する初期検查となっている，場合によっては脊 髄造影検查を行わずLSCS に対する観血的加療が行わ れているが，観血的加療に対する検查に脊髄造影を外 すことについては議論の余地が残されている. 動的要 素や軸圧負荷が LSCS の症状発現に重要な役割を果た しており，仰臥位で撮影する MRIでは動的要素や軸 圧負荷を含めた評価は不可能となる，今回の検討では LSCS の症状発現に重要とされる動的因子を評価する にあたって脊髄造影の有用性について腰椎 MRI との 比較検討を行った.

\section{対 象と方 法}

福岡市立病院で 2009 年 4 月から 2010 年 3 月に腰椎 MRI 㧍よび尙髄造影検查を施行した L $4 / 5$ に主病変 を有し当院で観血的加療をうけた症例を対象とした. 除外基準としては変性すべり症, 変性側弯症, 再手術 例, 圧迫骨折の既往がある例, 側面腰椎動態撮影で $3 \mathrm{~mm}$ 以上のすべり症の増悪を認めるものとした。

ほほ全症例 LSCSの診断のため外来で腰椎 MRI (PHILIPS Gyroscan NT Intera 1.5 T) を受けてお り, 水平断㧍よび矢状断で T 1 強調・ T 2 強調画像を 撮影した. 水平面では各椎間レベルで椎体終板に並行 に2〜4 画像, 矢状面では 11 画像撮影した。

本施設では手術加療を行う 2 日以上前に脊髄造影検

\footnotetext{
* 福岡市民病院整形外科 Department of Orthopaedic Surgery, Fukuoka City Hospital, Fukuoka, Japan
} 


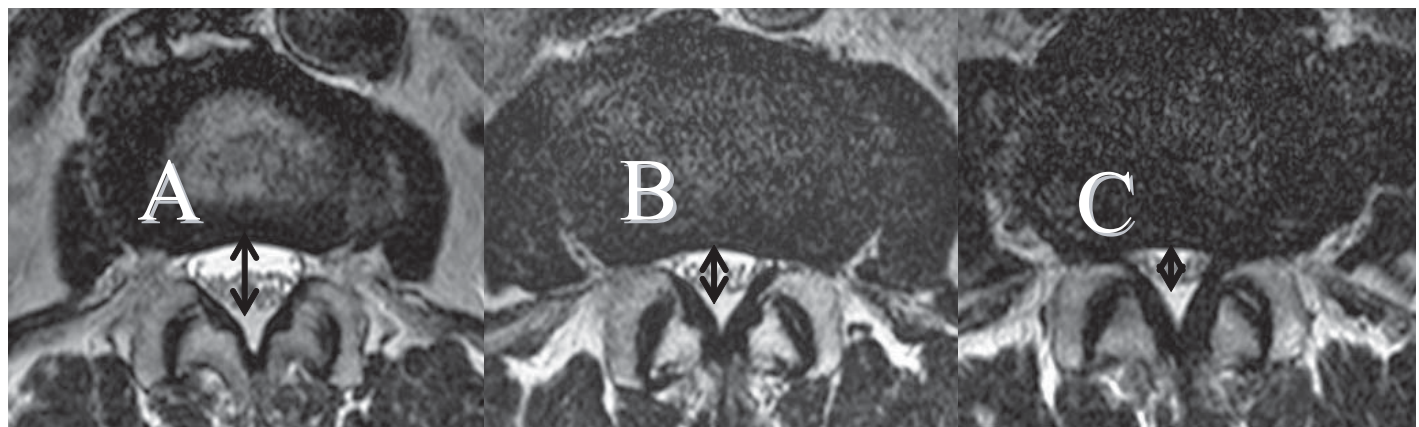

L 1

L $2 / 3$

L $3 / 4$

図 1 腰椎 MRI での前後径比の測定

$\mathrm{L} 2 / 3$ 前後径比 $=\mathrm{B} / \mathrm{A} 、 \mathrm{~L} 3 / 4$ 前後径比 $=\mathrm{C} / \mathrm{A}$

査とミエロ CT 撮影を施行しており, 春髄造影では造 影剤（オム二パーク 240）を脊䯣円錐のレベルに注意 をしながら LCSC を有する椎間レベルょり上位椎間 からクモ膜下腔に投与を行った。 PA 像を臥位と立位 で撮影し，側面像は中間位と伸展位・屈曲位・立位で 撮影した。ミエロCT は SOMATOM Definition AS+ を使用し $1 \mathrm{~mm}$ スライス $0.7 \mathrm{~mm}$ 幅で腰椎を撮影後に 再構成を行っている.

今回の研究では $\mathrm{L} 1$ 椎体後方の硬膜管前後径を絶 対値 1 として相対値を算出して評価を行った．腰椎 MRIでは T 2 強調画像水平断では各椎間で前後径比 を算出した（図 1)。脊髄造影検査では屈曲および伸 展位側面像で腰椎 MRI と同様に前後径比を算出した （図 2)。春髄造影では完全ブロックを認めた場合は同 レベル拉よびその下位レベルを評価の対象から除外し た。

評価の方法としては椎体間毎に腰椎 MRI ・脊髄造 影伸展位・屈曲位間で Mann-whitney U test で有意差 を算出した。

また，各椎間で手術症例数・腰椎 MRIでクモ膜下 腔の消失症例数も確認した。

\section{結果}

対象症例は除外症例を除き 30 例（男性 19,女性 11 例）となった。平均年齢は 71.4 歳（50-87 歳）であっ た．Ｌ $1 / 2$ 椎間では脊髄造影で完全ブロックを認める 症例はなく 30 例算出可能であった。 L $2 / 3$ 椎間では 1 例伸展位で完全ブロックを認め, 全 29 例算出した. L 3/4 椎間では 10 例伸展位で完全ブロックを認め,

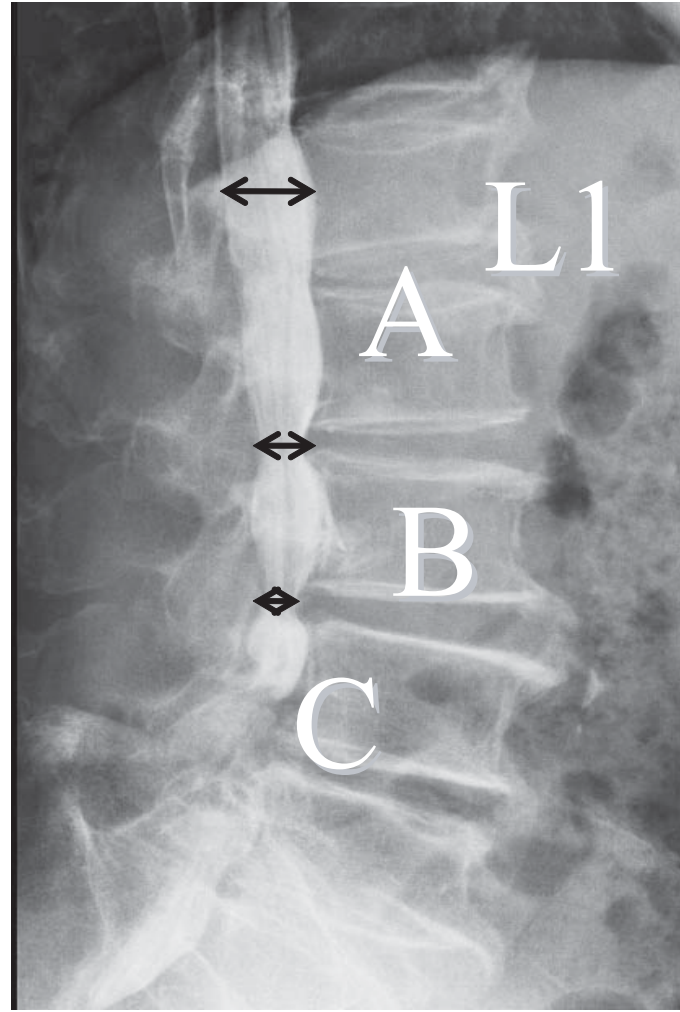

図 2 腰椎 MRI での前後径比の測定

$\mathrm{L} 2 / 3$ 前後径比 $=\mathrm{B} / \mathrm{A} 、 \mathrm{~L} 3 / 4$ 前後径比 $=\mathrm{C} / \mathrm{A}$

L 2/3 椎間レベルで算出可能であった 29 例からこの 10 例を除き 19 例算出した。 $\mathrm{L} 1 / 2$ 椎体間の平均值は 腰椎 MRI 0.866 · 脊髄造影伸展位 0.813 ・屈曲位 
表 1 各椎間・撮影方法での金柱管前後径比

\begin{tabular}{lccc}
\hline \hline & L $1 / 2$ 椎間 & L 2/3 椎間 & L 3/4 椎間 \\
\hline 腰椎 MRI & 0.866 & 0.83 & 0.679 \\
脊䯣造影伸展位 & 0.813 & 0.576 & 0.495 \\
脊髓造影屈曲位 & 0.867 & 0.751 & 0.652 \\
\hline
\end{tabular}

0.867 となった. L 2 $/ 3$ 椎体間では腰椎 MRI 0.830 • 脊髄造影伸展位 0.576 ·屈曲位 0.751, L $3 / 4$ 椎体間 の平均值は腰椎 MRI 0.679. 脊髄造影伸展位 0.495 • 屈曲位 0.652 であった（表 1 ）。椎体レベルごとに各 検査結果を比較したところ L $1 / 2$ 椎体間では脊髄造影 伸展位群と屈曲位群間で, L $2 / 3 \cdot \mathrm{L} 3 / 4$ 椎間では春髄 造影伸展位群と他 2 群間で大きな有意差 $(\mathrm{p}<0.01)$ を認めた（図 3～5)，各椎間を比較した場合，腰椎 MRI · 脊髄造影伸展位 ·屈曲位ともに下位椎間レベル ほど春柱管前後径は狭小化していた。

MRI でクモ膜下腔が消失していた症例は L $1 / 2$ 椎 間では 1 例もなく, L $2 / 3$ では 4 例，L $3 / 4$ では 17 例 認めた. 手術加療を行った症例は L $2 / 3$ では 7 症例, L 3/4 では20 例であった。腰椎 MRI でクモ膜下腔が 残存していたにも関わらず，脊髄造影の結果により手 術を施行した症例が L $2 / 3 \cdot$ L 3 / 椎間で各 3 例ずつ 認めた。

\section{考察}

非侵襲性である腰椎 MRI はペースメーカー移植術 後など一部の症例を除き初期検査として行われてい る。また，圧迫要因が腫瘍などの軟部組織によるもの であった場合はその質的評価にも有用である。一方, 春髄造影では完全ブロックとなる病変を同定できるの に対し侵襲性を伴う春髄穿刺を行わない限り評価は出 来ず，完全ブロックがあった場合は完全ブロックより 低位レベルの評価はできない3). しかし，腰椎の動態 要素は脊柱管狭窄症の症状発現に関与する重要な役割 を果たし，軸加重は脊柱管腔の減少を誘発する ${ }^{122)}$ 。こ のことが春髄造影をLCSC の評価項目から外すのを 困難にしている，後屈位 MRI 撮影により有用な評価

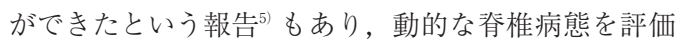
するのにOpen MRI は有効であるといわれているが まだ広く普及していない. Open MRI 撮影を行うに当 たっても, 軸圧負荷により強い症状を示す症例では MRI 撮影中の姿勢保持が困難となり評価が困難とな

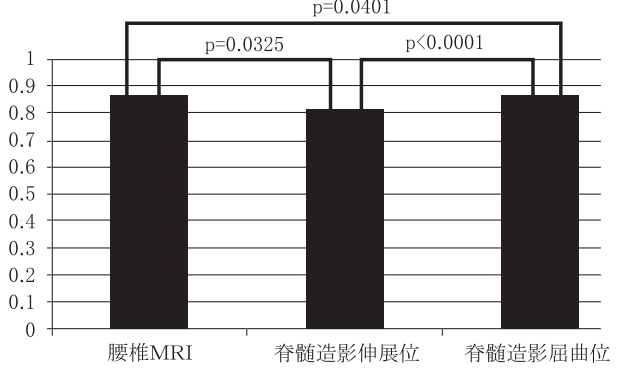

図 3 L $1 / 2$ 椎間板レベルでの比較

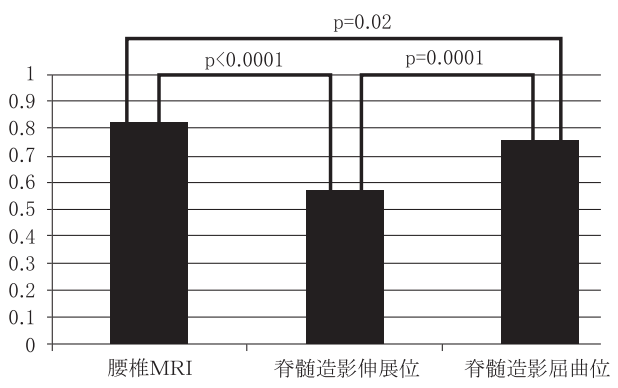

図 4 L 2/3 椎間板レベルでの比較

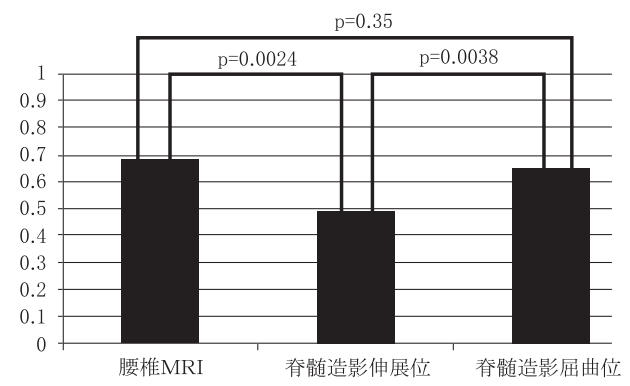

図 5 L 3/4 椎間板レベルでの比較

ることが予測される，さらに，春柱管狭窄や椎間孔狭 窄の原因となる変性や椎間関節の肥大といった骨病変 については MRI 単独では評価が難しい.

画像上 LCSC の重症度により手術範囲は決定され るにも関わらず，LSCSの重症度を決定する広く使用 される基準は確立されていない. MRI もしくは脊髄 造影に関して客観的基準を設定するのは困難で，多病 変を有する患者に対応させるのは特に困難である．横 断面の脊柱管腔は純粋に客観的な評価となり，クモ膜 下腔の狭小化と術前の春柱管狭窄症による症状の相関 
性は早くから指摘されているにも関わらず，脊柱管の 大きさに個体差があり各々の症例を大きさだけで評価 するのは難しいとされる ${ }^{4)}$ 。この事実からも手術部位 は術者の主観によって決定されており，術者や術前画 像により違いが出る傾向がある.

本研究では LCSC の評価として腰椎 MRI・脊髄造 影伸展位・屈曲間の春柱管前後径を検討した，MRI よりも春髄造影伸展位で硬膜管前後径比が小さい傾向 を認めた。病変を有する可能性の高い下位椎体レベル で脊髄造影伸展位に有意差を認めることから, 脊髄造 影伸展位撮影は動的要素負荷により LCSCに伴う狭 小化を最も評価している可能性が示唆された. LCSC の病態を踏まえると腰椎 MRI は仰臥位での撮影であ るため, 脊髄造影屈曲位での春柱管前後径が最も大き くなることを予測していたが今回腰椎 MRI で最も前 後径比が大きくなっていた。 このことは今回水平断で 腰椎 MRI を撮影したが各椎体レベルで 3 スライスで しか評価しておらず，最も狭窄の程度が強い部位を撮 影出来ていなかったためと考えられた。以上から腰椎 MRIの一般的な撮影方法ではLCSC の重症度を正確 に評価できていない可能性があり，腰椎 MRI 撮影に あたっても詳細に評価が可能なマルチスライス撮影な ど撮影方法の工夫が必要と考えられた。

しかし，今回の研究においてもいくつかの制限があ ると考えなければならない.今回の研究ではLSCSを 評価する脊柱管腔面積の計測などを行っておらず，前 後径比が直接的に症状に関与することを示唆するわけ ではないため前後径比の低下の臨床的な意義について
論じることはできていない。また，対象症例数が 30 例と少なく，今後症例数を増やし検討を加える必要か あると考えられた。

\section{結語}

当科において全髄造影・腰椎 MRIを撮影した LCSC 症例の硬膜管前後径を比較検討した。硬膜管前 後径は下位椎体レベルほど狭小化していた。 MRIで は脊髄造影伸展位で狭窄の出現する椎間を過小評価す る可能性が示唆された。今後は非侵襲的かつ動態評価 も可能な検査方法の確立が期待される.

\section{参 考 文 献}

1) Danielson, B.I., et al. : Axial loading of the spine during $\mathrm{CT}$ and MR in patiens with suspected lumbar spinal stenosis. Acta Radial., 39:604-611, 1998.

2) Elsig, J.P., et al.: Dynamic imaging of the spine with an open upright MRI: present results and futures perspectives of fmri. Eur. J. Orthop. Surg. Traumatol., 17 : 119-124, 2007.

3) Lian, P., et al. : Correlative study on findings of dynamic myelography and surgical operation in non-bony lumbar spinal canal stenosis. Chin. Med. J., 107:924928, 1994.

4) Morita, M., et al. : Comparison between MRI and myelography in lumbar spinal canal stenosis for the decision of levels of decompression surgery. J. Spinal Disord. Tech., 24(1): 31-36, 2011.

5）内田 仁ら：腰部脊柱管狭窄症における MRI ミエログ ラフィーの動態撮影の検討. 整外と災外，51(2)：329332, 2002. 